\title{
DOKTOR JACEK JUZWISZYN (1971-2015)
}

\section{Małgorzata Kosielińska, Antoni Smoluk}

Dimitte nobis debita nostra...

DOI: $10.15611 / \mathrm{dm} .2016 .13 .10$

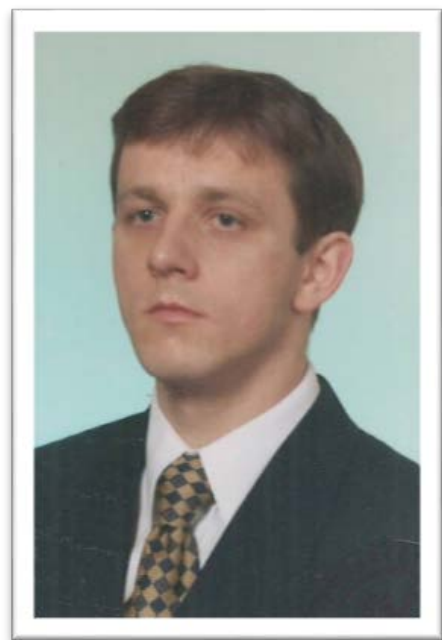

wywołała wiele dyskusji i emocji w środowisku naukowym. Naczelną tezą doktoranta jest stwierdzenie, że prawa nauki są uniwersalne i te odkryte przez fizyków również obowiązują w ekonomii. Zasadniczym prawem przyrody jest powszechnie obowiązująca zasada równowagi przejawiająca się w wirach tak często spotykanych w naturze. Historia wirów ekonomicznych ma swój początek w schemacie pajęczynowym, pokazującym, jak dochodzi się do punktu równowagi podaży z popytem.

Adiunkt Katedry Matematyki i Cybernetyki; pracował również krótko w innych firmach, takich jak: Deutsche Bank, Bank Gospodarczy, Bank Spółdzielczy. Na licznych konferencjach naukowych i dydaktycznych refe-

\footnotetext{
Małgorzata Kosielińska, Antoni Smoluk

Department of Mathematics and Cybernetics, Wrocław University of Economics math@ue.wroc.pl
} 
rował swoje pomysły naukowe i propozycje dydaktyczne. Jego dorobek liczy kilkadziesiąt artykułów. Głównym odkryciem jest spostrzeżenie, że zygzaki, które obserwujemy na wykresach danych giełdowych, są rzutem płaskim wiru spiralnego na stożku. Kilkakrotnie brał udział w pracach Festiwalu Nauki Polskiej, gdzie przedstawiał najnowsze wyniki szerokiej publiczności. Był aktywny pod względem naukowym, dydaktycznym i organizacyjnym. Jego propozycje rozszerzenia przestrzeni dydaktycznej na Śląsku spotkały się z ciepłym przyjęciem, chociaż w pełni nie zostały zrealizowane. Członek Polskiego Towarzystwa Matematycznego - pracował przez kilka lat w zarządzie oddziału wrocławskiego, a także Polskiego Towarzystwa Statystycznego. Przez kilka kadencji był prodziekanem Wydziału w Wyższej Szkole Handlowej we Wrocławiu.

Troskliwy mąż i ojciec, dumny z osiągnięć swych dwóch córek na szkolnych olimpiadach informatycznych. Sam przygotowywał je do tych zawodów. To typ człowieka potocznie zwanego angielskim słowem fighter. Uważano, że dobra doczesne czerpał pełnymi garściami, jednakowoż cukrzyca, na którą cierpiał, hamowała jego naturalny pęd życiowy. Zginął w apokaliptycznych płomieniach własnego domu w nocy nad ranem 12 listopada 2015 roku - wielka strata. Śmierć ta dała asumpt do licznych spekulacji i to tak niezwykłych, jak te tyczące się katastrofy smoleńskiej. Prochy jego złożono na cmentarzu kiełczowskim we Wrocławiu. Jego współpraca z prof. Aleksandrem Jakimowiczem z Instytutu Nauk Ekonomicznych Polskiej Akademii Nauk zaowocuje książką o wirach i równowadze. Idee rozwijane przez niego są ciągle żywe. Prawo równowagi jest jedynym i powszechnym prawem całej nauki. Idealny mężczyzna - żył jak Herkules i zginął jak Herkules. 